〔ミニレビュー〕

\title{
ゲノム情報と家畜育種
}

長嶺慶隆

日本大学 生物資源科学部 動物資源科学科

\section{Genomic information and animal breeding}

\author{
Yoshitaka NAGAMINE \\ Nihon University, 1866 Kameino, Fujisawa, Kanagawa 252-0880, Japan
}

\begin{abstract}
要約
現在、数万〜数十万という膨大な数の SNP マーカーの情報を用いてポリジーンの動きを捕らえようとしている。 大量マーカーの利用は全 SNP を用いてゲノミック育種価を推定する方法と、有用な SNP の探索に重点を置く手法 がある。家畜のゲノミック選抜には前者が用いられ、後者はGWAS (genome-wide association study) と呼ばれ医学 分野を中心によく用いられる。しかしゲノミック選抜ではGWAS で探索した有用な SNP 独立した効果として用 いることもできる。また全 SNPを使って個体間の遺伝的な関係を構築し、ゲノミック育種価を推定する方法もある。 この方法ではこれまで血統をもとに作成していた個体間の遺伝的関係を対立遺伝子の共有状態（IBS）をもとに構 築し、全個体の遺伝的関係をゲノミック行列として利用する。また有意な SNP 領域を新たな領域ゲノミック行列 として加え、領域における育種価を推定する方法も提案されている。

本稿ではこれまでの育種研究の流れを述べ、最新の領域ゲノミック行列を用いた手法とその手法を適用したヒト と乳牛のデータでの解析結果を紹介する。
\end{abstract}

\section{1.はじめに}

これまでの家畜育種学では、量的形質（増体速度， 泌乳量など）といわれるものは染色体上の位置もまた 遺伝子の効果も特定できない大量のポリジーンにコン トロールされるという仮定で研究も実際の改良も進め てきた（Falconer 1960; Henderson 1984)。しかし Andersson ら (1994) がイノシシと豚の交雑種を使い QTL（量的形質遺伝子座）を報告して以降、1990 年代 半ばからは数十から数百の遺伝マーカー（マイクサテ ライトマーカー）を使い効果の大きい QTLを探索する 研究が盛んに行われるようになった。マイクロサテラ イトは多型性が高いことからマーカーとして優位な点 もあるが、全染色体上に数百個程度しか配置できない (Knott ら 1998; Schnabel ら 2005)。現在、盛んに用いら れる SNP (Single Nucleotide Polymorphism) マーカーは 1 座位の対立遺伝子が 2 個しかなく多様性は少ないが家 畜で数万〜数十万、ヒトでは 100 万個以上を染色体上に 配置できる。数百程度の数のマイクロサテライトの場 合に比べ、SNP ではマーカーの数が 100 倍、1,000 倍と
増えたため、従来のマーカー数を想定した QTL 探索と 条件が大きく異なる。例えば、隣接したマーカーの距 離が $5 \mathrm{cM}$ （組み換え率 5\%) ある場合は組み換え率を 考えた QTL 推定が必要だが (Pong-Wong ら 2001; Nagamine ら 2004)、1cM 内に 100 マーカーもあれば隣接 したマーカー間の組み換えは考慮する必要がなくなる。

乳牛の改良に関して北米では SNP マーカーと古い世 代の育種価推定值をもとに、娘牛を持たない若雄につ いてもマーカー情報だけでその遺伝的能力を判定しよ うとしている（Sullivanら 2011; VanRaden 2008; VanRaden ら 2009)。本稿ではこれまでの育種研究の 流れを述べ、ヒトと乳牛のデータについて、ゲノム情 報を使った解析結果を紹介する。本論文中ではゲノム 情報という言葉を 全染色体に配置した大量のSNPに

連絡先 : 長嶺慶隆 日本大学 生物資源科学部 動物資源科学科 T 252-0880 神奈川県藤沢市亀井野 1866 (email: nagamine.yoshitaka@nihon-u.ac.jp) 
ついて統計処理をして得られた量的形質に関する有用 な遺伝情報という意味で用いる。またポリジーンの効 果については相加的な効果のみ対象にしている。

\section{2. 大量のマーカーを使った育種価推定の始まり}

2001 年に Meuwissen らが大量の遺伝マーカーを用い ることにより、表型值を用いずに育種価推定が可能に なるという論文を発表した。シミュレーションを用い た結果だが、対象形質に関与する遺伝子と連鎖不平衡 の状態にある近傍マーカーのハプロタイプを利用して 育種価を推定するという構想である。

Meuwissen は（1）最小二乗法、（2）BLUP 法、(3) ベイズ法の 3 つの方法で大量マーカーによる育種価の 推定を考えた。（1）の最小二乗法ではマーカー毎に一 定の基準で効果をテストし、有意でないものは効果を 0 とし、効果の大きなマーカーだけを全て同時に用い て育種価を推定した。この方法は各マーカーの効果は 母数効果と考えるため分散を考慮する必要がない。し かし個体毎の測定值（各個体 1つ）数に比べ、取り达 むべきマーカー数が多いと自由度が不足するという問 題を持つ。一般式で言えば従属変数 Y (測定值) の数 に対し独立変数 X（マーカー）が多すぎて計算不能と いう事態になる。（2）の BLUP 法による推定は全マー カーの効果をランダム効果と考えるため、マーカー数 に比べて個体数（測定值）が少なくても自由度不足と いう問題は避けられる。しかし、全てのマーカー遺伝 子の効果の分散を同一と仮定する必要がある。現実に は特定の形質に関しては一部のマーカーは関与する が、多くのマーカーは効果が無い（つまり分散は 0) と考える方が自然であり、非現実的な仮定ともいえる。 （3）のベイズ法による推定は上記の BLUP の欠陥を補 う方法であり、多くのマーカーは効果が無いが（分散 $=0$ )、一部のマーカーは効果を持つという仮定が可能 である。彼らはべイズに関して2 法 (A: 全マーカー座 位に関して逆カイ二乗分布を仮定、B: 一部の座位に関 しては A と同様だが多くのマーカーの効果は 0 を仮定) を検討した。ここではより精度の高かった B のベイズ 法の結果を取り上げる。シミュレーションでは古い世 代（トレーニング集団）は表型值とマーカー遺伝子型 の両方を持ち、その条件下で遺伝子型から育種価の推 定を行う、そして遺伝子型のみ持つ新しい世代（検証 集団）に扔いてどの程度、真の育種価と推定育種価が 相関（正確度）を示すかを見た。その結果、正確度の 高い順にベイズ法 (0.85)、BLUP 法（0.73）となり、 最小二乗法は正確度 0.32 と最も低かった。発表当初
は大量のマーカーの利用は非現実的であり批判的な意 見も多かったが、その後、家畜においても安価で大量 のSNP が入手可能となり、また乳牛育種での費用対効 果が非常に高い（Schaeffer 2006）ことから、脚光を浴 びるようになった。従来の乳牛改良においては、雄牛 自身は泌乳記録を持たないため種雄候補牛の娘牛の泌 乳量を測定し、その結果を用いて父である雄牛を選抜 する。この場合、種雄候補牛と雌牛の交配、娘牛生産、 娘牛の種付けと分娩、そして分娩後の泌乳記録を用い ることにより初めて種雄候補牛の評価が可能となる。 しかしゲノム情報を用いた選抜（ゲノミック選抜）で は娘牛を作るための交配から泌乳記録による種雄牛の 評価までの年数（約 4 年間）を省略し、種雄候補牛が 生まれた時点でその牛のゲノム情報から育種価推定が 可能になる。若齢の雄牛の使用が可能になることによ り世代交代が早まり、一定期間での改良量は 2 倍にな る。また従来の後代検定に比べゲノミック選抜は費用 面で最大 $92 \%$ 減少すると言われる（Schaeffer 2006）。

\section{3 ゲノミック育種価と様々なモデル}

Meuwissen ら（2001）の研究をもとに、家畜分野で 発展したゲノミック選抜ではBLUP 法あるいはべイズ 法を適用し、個々の SNP が有意か否かにかかわらず、 大量の SNPを用いて推定した育種価をもとに選抜を行 う方法が主流である（Haleyと Visscher 1998; Meuwissen 2007)。一方、GWAS (genome wide association study) という用語は特定の遺伝子と連鎖不平衡の状態にある 統計的に有意なSNPを特定する研究で使われ (Aulchenko ら 2007; Iwaisaki ら 2010)、医学分野で多 く用いられる。しかし GWAS で検出された有意な SNP 効果を使い、さらに全 SNPを用いて残りのポリジーン を捕捉する方法もある。

Meuwissen ら (2001) のシミュレーションでは、真 の育種価とマーカーを用いた育種価推定値の相関は最 も精度の高い方法 (ベイズ B 法) で 0.85 あり、大量の マーカーを用いることで育種価をかなり正確に推定し ている。しかし、現実にゲノム情報でどこまで従来の 育種価が説明できるか疑問である。

我が国では佐分（2010）が検定済み乳牛の種雄牛約 2,000 頭をトレーニング集団とし、若い種雄牛 500 頭を 検証集団としてゲノミック選抜に関する研究を行っ た。その結果、泌乳や体型形質など計 21 形質において SNP 情報を用いた信頼度は従来の血統情報のみ用いた 場合よりは高かった。しかし信頼度の増加が小さいこ とから、これまでの検定・選抜方法を大きく変えるも 


\section{ゲノム情報と家畜育種}

のではないとしている。

海外でも乳牛の SNP 情報から求めたゲノミック育種 価と従来の方法で求めた育種価の相関は必ずしも高く ない。Mrode（2012）は乳量で 0.67 程度の相関を報告 している。また従来法による育種価のゲノミック育種 価に対する回帰係数は 1 より小さく、ゲノミック育種 価は従来法より過大な評価值となる場合が多い（Gao ら 2012)。こうした差を埋めるため乳牛のゲノミック 選抜のための統計モデルでは SNP による育種価の項に 加え、SNPで説明できない残余ポリジーン（residual polygenic effect）を用いる。Mrode（2012）は乳量に関 して残余ポリジーンの分散を全遺伝分散の 20 25\%に してモデルに加えた場合、ゲノミック評価值の偏りが 補正され回帰係数が 1 に近くなったと報告している。 しかし 20 25\%の分散割合について理論的な根拠はな く、いくつかの数值を試して結果として最適なものを 使用するのが現状である。

家畜のゲノミック選抜に直接のかかわりはないが、 GWAS の視点から SNP の効果について見てみる。結論 から言えば、有意な効果の SNP を集積しても従来の遺 伝分散は十分に説明できない。ヒトの遺伝分野では、 ゲノム情報を利用しても従来の遺伝率が十分説明でき ないという missing heritability (Maher 2008) が話題に なった。例えば身長の遺伝率に関して、これまで発見 された有意な遺伝子の効果を全てあわせても従来の遺 伝率のわずかな部分しか説明できない。ヒトの身長の 遺伝率は、これまで血統を用いた分散分析や親子回帰 など様々手法で推定されており、通常は 80-90\%の高 い推定值が得られる。しかし個々の有意な SNP マー カーで推定された全ゲノム上の遺伝率の総和は $10 \%$ 程 度しかなく、この差 (70-80\%) となる失われた遺伝率 は大量の SNPを用いても十分な説明ができなかった (Lettre ら 2008; Weedon ら 2008)。その後、一定以下の 血縁関係のものだけのデー夕を扱うなどの作業を行い 説明可能な遺伝率は上がったが（Yang ら 2010）、まだ 十分説明できるとは言えない。

ここでSNP の効果を検出するためにモデル式（1） を示しておく，一般にはこの式に性や年齢などを母数 効果として加えて補正する（Aulchenko ら 2007）.

$$
y=1 \mu+W g+e
$$

$y:$ 測定值のベクトル $, 1: 1$ からなるベクトル $\mu:$ 全平 均 $W: \mathrm{SNP}$ の遺伝子型（例 $\mathrm{AA}=0, \mathrm{AC}=1, \mathrm{CC}=2$ ）の ベクトル g: SNP の遺伝子型で説明できる相加的な遺伝 的効果のベクトル (回帰係数) e : 誤差のベクトル i 番目の SNP の効果 gi が有意（有意な回帰）であれば、 この SNP は形質に関して遺伝的な役割を持つと判断され る。実際はこのSNP 自体は単に標識 (マーカー) なので、 この SNP と連鎖している遺伝子に関する判定になる。

また小さな効果を持つ大量のポリジーンによる効果 と影響の大きい遺伝子の効果を分けて推定する方法も ある。ここでは染色体上にほほ均一に分布し、また効 果が小さく隣接した SNP との連鎖不平衡を利用しても 検出できないものを（便宜的に）検出不能なポリジー ンと呼ぶ。次式（2）はこの検出不能なポリジーン全 部での効果と有意な SNP の効果という2 つの遺伝的な 効果を同時に推定するためのモデルである（Aulchenko ら 2007).

$$
y=1 \mu+W g+Z u+e
$$

$y:$ 測定值のベクトル、1:1 からなるベクトル、 $\mu$ : 全平 均、W: 有意な SNP の遺伝子型のベクトル、g: SNP の 遺伝子型で説明できる相加的な遺伝的効果のべクトル (回帰係数)、 Z: 各個体に対応するデザイン行列、u: マーカーでは検出不能なポリジーン全部の効果、e : 誤 差のベクトル

この式は Hendersonの Mixed Model (Animal Model) にSNP 効果の項を加えたものである。A を血統に基 づく相加的血縁係数行列とするとポリジーン部分の分 散は $A \sigma_{\mathrm{u}}^{2}$ となる。また $\mathrm{A}$ 行列の代わりに SNPを使っ て求めたゲノミックな近縁関係からつくる $\mathrm{G}$ 行列（ゲ ノミック行列）も使用できる。 $\mathrm{G}$ 行列の作り方はいく つか考えられるが基本的には 2 個体間の SNP の似通い から Identity by State（IBS）を計算し, 全 SNPについ て積算して求める（Purcell ら 2007; Nejati-Javaremi ら 1997; VanRaden 2008)。これを全 SNPを用いて個体間 の総当りで行えば全個体間での $\mathrm{G}$ 行列が作成できる

2 個体が同じ遺伝子を持つほど個体間の $\mathrm{G}$ の要素は 大きくなり，逆に異なる遺伝子を多く持てば小さくな る。G 行列を用いたモデルは GBULP とも言われるが、 一定条件の下では Meuwissen ら（2001）が BLUP と呼 んだ方法と同じになる（Hayes ら 2009）。また全 SNP を用いて $\mathrm{G}$ 行列を作る以外にも特定領域の遺伝子の効 果を見るために数十から数百の SNP 毎に G 行列を作 ることもできる。

\section{4. ゲノミック行列を用いた解析例（ヒトと乳牛）}

ここでは特定領域の SNP から G 行列を作成し、特 定領域の効果を探索したヒト（Nagamine 2012a）と乳 牛 (Nagamine 2012b) の例を紹介する。領域ゲノム分散 
あるいは領域ゲノム遺伝率法 (Regional genomic variance あるいは Regional genomic heritability）と呼ぶ 方法により、特定の形質に関して染色体上の有意な領 域を探索できる。 3,039 人のヒトに関して尿酸と身長 のデータ及び 30 万座位の SNP タイピングデータを用 いた。モデル式は

$$
y=X \beta+Z u+Z w+e
$$

ここで分散は $\operatorname{Var}(\mathrm{u})=\mathrm{G} \sigma \mathrm{u}^{2}, \operatorname{Var}(\mathrm{w})=\mathrm{Q} \sigma \mathrm{w}^{2}, \operatorname{Var}(\mathrm{e})=\mathrm{I} \sigma \mathrm{e}^{2}$ $\mathrm{G}$ 行列は全 SNP を使って作成し、Q 行列は特定領域 の数十あるいは数百の SNP を用いて作成する。ここで $y$ : 表型值ベクトル、 $x$ : 母数効果のデザイン行列、 $\beta$ : 母 数効果（性、年齢など）のべクトル、Z: 変量効果のデ ザイン行列 u: 全 SNP を使った全ゲノムでのポリジー ン効果のベクトル、w: 一部の SNPを用いた特定領域 （領域ゲノム）でのポリジーン効果のベクトル、e: 残差 のベクトル。

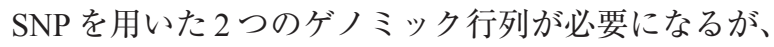
一つは全 SNP を使った G 行列（全ゲノミック行列）、 もう一つは連続した少数（数個〜数百）のSNP を使用 した Q 行列（領域ゲノミック行列）である。今回の解 析では 100SNPを用いて G 行列を作成したが、さらに 大きな SNP 数でも良い。また 100SNPを用いて有意な 領域をある程度特定してから、20SNP、さらに10SNP と SNP 数を小さくして詳細な領域を見ることも可能で ある。

$\mathrm{G}$ 行列と $\mathrm{Q}$ 行列が同じような行列の場合 $(\mathrm{G} \doteqdot \mathrm{Q})$ は解が不安定となり、時には収束しないといった問題 が生じるが、扱ったデー夕の範囲内ではこの問題は生 じなかった。また少数の SNPでQ行列を作った場合(例 10SNP 以下)、全く同じ SNP 遺伝子型を持つ個体が 複数出現する可能性があり、この場合 $\mathrm{Q}$ 行列の逆行列 は解けなくなる。著者の経験では乳牛のように選抜が 進んだ集団ではヒトより多様性が少ないため、領域に よっては20SNP からなる Q 行列でも逆行列が解けな いケースも稀にあった。

ヒトの解析例ではまず 100SNP から作った Q 行列を $50 \mathrm{SNP}$ 毎移動させながら次々とその有意性をテストし た。領域毎の Q 行列に用いた SNP 群をウィンドウ (window) と呼ぶが、この場合、第1ウインドウは 1 100SNP、第 2 ウインドウは 51 150SNP, 第 3 ウイン ドウは 101 200SNP となる。第 1 から第 22 染色体まで の（性染色体を除く）全染色体上の約 30 万の SNPに 対し 5511 ウィンドウをテストした。この手法では相加 的な遺伝分散が全 SNP 用いた G 行列によるものと
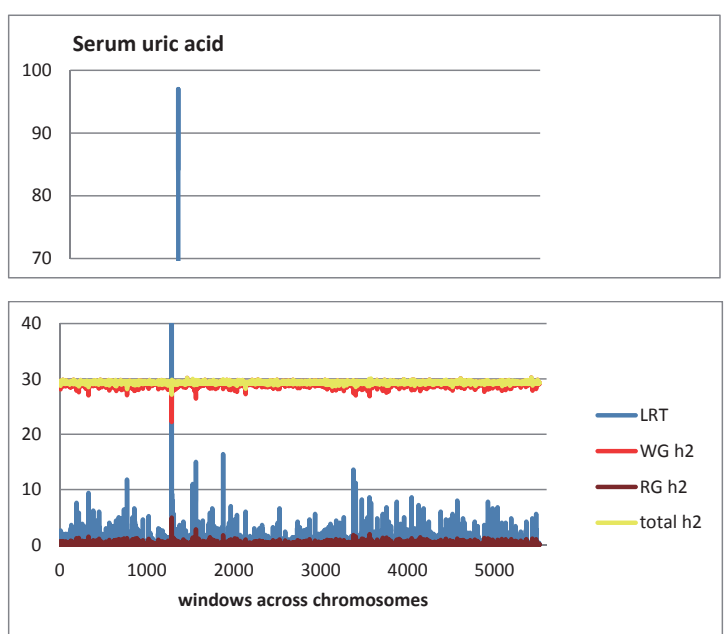

図 1 尿酸值に関する統計值（LRT）と全ゲノム、領域 ゲノムによる遺伝率

全染色体（第 1 - 22 染色体）のSNP（約 30 万）を連続した 100SNP 毎に用いて領域での遺伝率を推定した。縦軸は遺伝率と 統計值（LRT が高いほど有意）、横軸は 100SNP からなる領域を 50SNP 毎に移動した window 番号。全ゲノム遺伝率（WG h2）、 100 S N P を使っての領域 (window) 毎の領域ゲノム遺伝率 (RG h2)、そしてその 2 つ遺伝率の和を全遺伝率（Total h2）とし て示した。
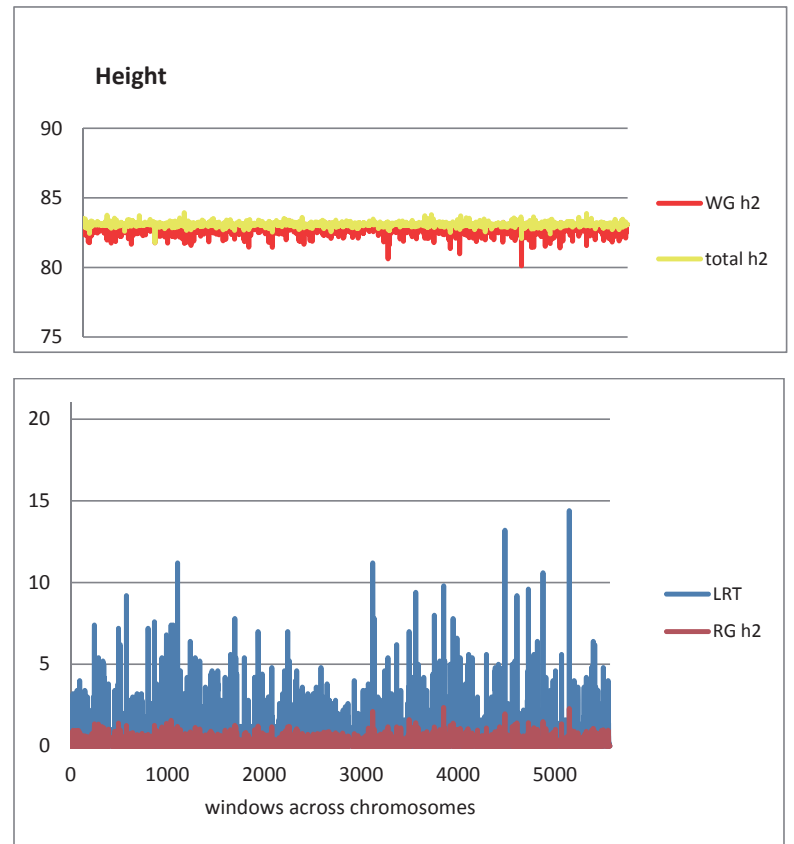

図 2 身長に関する統計值（LRT）と全ゲノム、領域ゲ ノムによる遺伝率

全染色体（第1-22 染色体）のSNP（約 30 万）を連続した 100SNP 毎に用いて領域での遺伝率を推定した。縦軸は遺伝率と 統計値（LRT が高いほど有意）、横軸は 100SNP からなる領域を 50SNP 毎に移動した window 番号。全ゲノム遺伝率（WG h2）、 100SNP を使っての領域（window）毎の領域ゲノム遺伝率（RG h2)、そしてその 2 つの遺伝率の和を全遺伝率（Total h2）とし て示した。 
$\mathrm{Q}$ 行列による特定領域での遺伝分散に分けて推定され る (Hayes ら 2010; Nagamine ら 2012a)。そこで Gと Q 行列による遺伝分散の和（トータルの相加的遺伝分散） に占める Q 行列による遺伝分散の割合を領域ゲノム遺 伝率（Regional genomic heritability）と名付けた。図 1 は尿酸值についての解析結果である。尿酸值では第 1285 ウィンドウ（第 4 染色体の先頭に近い箇所）付近 で非常に大きな統計值（LRT:97）が得られ、ここでの 領域遺伝率は $4.93 \%$ となった。この領域には尿酸値に 影響を与える遺伝子の存在がすでに知られている (Vitart ら 2008)。図 1 では G 行列による全ゲノム遺伝 率と $\mathrm{Q}$ 行列による領域ゲノム遺伝率、そして2つの遺 伝率の和を全遺伝率として示している。領域ゲノム遺 伝率が増えるウインドウでは全ゲノム遺伝率が減少 し、その結果、全遺伝率はほぼ一定の值（約 29\%）を保っ ていることから、全ゲノムでの遺伝分散と領域の遺伝 分散は分離されて検出されていることが推察できる。

図 2 は身長に関して図 1 と同様の項目を示したもの である。身長は尿酸値のように著しく高い LRT 值を示 すウィンドウはなかった。しかし、効果のある遺伝子 は全染色体上に均一にあるのではなく、所々（例 第 5148 ウィンドウ）に大きな効果をもつ領域があること が示唆される。これらの例では Q 行列に 100SNPを使っ たが、有意な領域が見つかれば使用するSNP の数をさ らに減らして狭い範囲に領域を特定できる。眓 3 は図

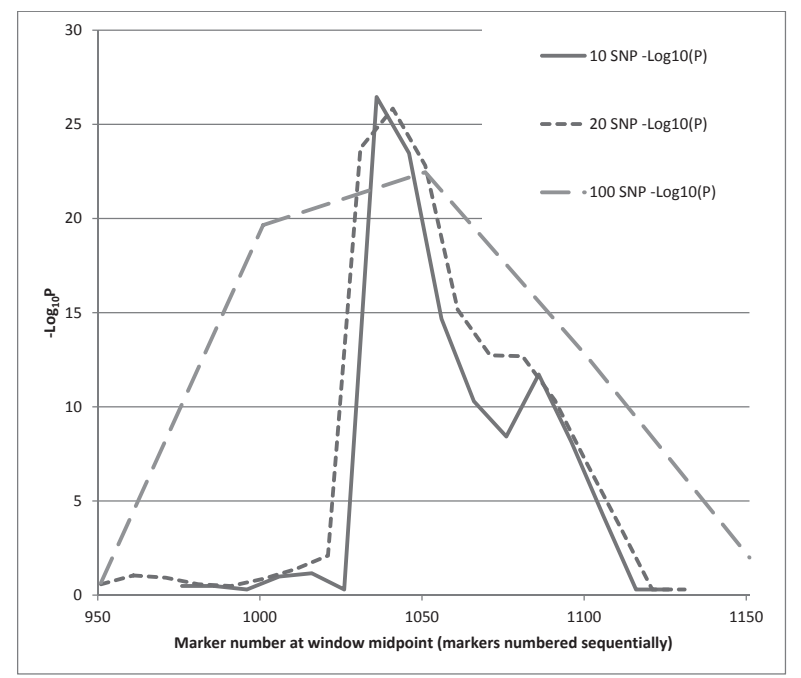

図 3 異なる S N P 数を用いて解析した領域ゲノムでの 統計値の比較

尿酸值に関する第 4 染色体上での有意な領域について 100、20、 10 の異なる SNP 数を用いて領域ゲノムの有意性を見た。領域用 の行列を作成する SNP 数が 100、20、10 と小さくなるにつれて 統計值 $(-\log 10 \mathrm{P})$ が大きくなり、また有意な領域も狭くなった。
1 の尿酸值に関するピークを示す区間（第 4 染色体上 で 950-1150 番目の SNP）について、Q 行列を作るため の SNP 数を 100、20、10 と減少させ、さらに有意な領 域を探ったものである。100SNPを用いた場合、ピー クは1001-1100番の中間 1051 番目の SNPで統計值 （-Log10P） 22.4 を示したが、20SNP,10SNP と使用する SNP 数を減らすことでピークの領域は狭まり、最終的 には1031-1040 番の中間 1036 番目の SNP で最大の統 計值 26.4 が得られた。

次に乳牛に扔ける Q 行列を用いた領域ゲノム分散法 の解析例を示す (Nagamine 2012b)。ホルスタイン種雄 牛 2590 頭の 305 日乳量 (MLK)、乳脂量 (FAT)、乳夕 ンパク質量（PRT）について従来の血統情報を用いて 推定した育種価及び 40,646 座位の SNP マーカー情報 を使用した。100SNPを用いた Q 行列で全染色体上を 順次探索し、第 14 染色体の 1 番目のウィンドウにピー クを検出した。この箇所の統計值 (LRT) は MLK (130)、 FAT（199）、PRT（32）と形質によって異なるがいず れも高度に有意であった。そこで、この領域について 20SNPを用いた Q 行列により再度解析を行った。この 手法では全 SNP を使った $\mathrm{G}$ 行列、領域の SNP を使っ た $\mathrm{Q}$ 行列により遺伝分散だけでなく、それぞれの行列 を使い全ゲノムによる育種価と領域ゲノムによる育種 価の推定が可能である。そこで、各個体の全ゲノムに よる育種価と第 14 染色体先頭箇所の 20SNPによる領 域ゲノムによる育種価間の相関を表 1 に示した。 MLK、FAT、PRT に関して全ゲノムによる育種価間の 相関は 0.789 (MLK:FAT)、0.858 (PRT:FAT)、 0.908 (MLK:PRT) と高い正の值であったが、第 14 染色体先 頭箇所 (20SNP) の領域から推定した育種価間の相関 は -0.943 (MLK:FAT)、-0.893 (PRT:FAT)、 0.980 (MLK:PRT) となり、脂肪量と他の形質間で大きな負 の値を示した。この領域には DGAT1 という乳脂肪や 脂肪蓄積に関与する遺伝子が知られている (Winter ら 2002; Fortes ら 2009)。今回の結果からポリジーンの遺 伝相関は全ゲノムでの值と、特定領域での值は異なる 可能性が示唆された（Spelmanら 2002）。こうした情 報は今後の各形質に対する選抜方法にも影響を与える だろう。

このようにヒトや乳牛での事例を見ると、単純に $\mathrm{G}$ 行列のみ用いて全 SNP の効果をゲノミック選抜に用い るのではなく、特定領域や有意な SNP 情報を組み合わ せた方がより正確な遺伝的能力の推定になることがわ かる。 
表 1. 乳牛における全ゲノムと特定領域ゲノムにおける 3 形質の育種価推定値の相関

\begin{tabular}{|c|c|c|c|c|c|c|c|}
\hline & & \multicolumn{3}{|c|}{ 全ゲノム } & \multicolumn{3}{|c|}{ 領域ゲノム } \\
\hline & & MLK & FAT & PRT & MLK & FAT & PRT \\
\hline \multirow[t]{3}{*}{ 全ゲノム } & MLK & 1 & 0.789 & 0.908 & 0.188 & -0.152 & 0.200 \\
\hline & FAT & & 1 & 0.858 & 0.179 & -0.154 & 0.181 \\
\hline & PRT & & & 1 & 0.226 & -0.184 & 0.238 \\
\hline 領域 & MLK & & & & 1 & -0.943 & 0.980 \\
\hline \multirow[t]{2}{*}{ ゲノム } & FAT & & & & & 1 & -0.893 \\
\hline & PRT & & & & & & 1 \\
\hline
\end{tabular}

\section{5. おわりに}

これまでの家畜改良のための理論は染色体上の位置 も効果も不明な大量なポリジーンを仮定して成り立っ ている。この仮定の下で様々な理論が作られ、そうし た理論を活用し実際に家畜の能力は大きく改良され た。Mixed model を開発した Henderson は血縁個体の情 報を余すことなく利用できるアニマルモデルを提案し （1973）、そのために必要な手法を Schaeffer ら優秀な弟 子や仲間とともに開発した。現在、家畜改良のために 用いられるモデルは基本的には Hendersonの Mixed Model をもとに作られている。こうした大きな流れの 中で現れた Meuwissen ら（2001）による大量マーカー を使ったゲノミック育種価の推定方法は革新的であ り、Hendersonのアニマルモデルを越える手法のよう に思われた。しかし大量のマーカーによっても育種価 は十分説明できず、残余ポリジーンの処理にはやはり Hendersonの手法が必要になる。ヒトでの報告 (Visscher ら 2007）を見る限り、量的形質に関する遺伝子の多く は個々の効果も小さく全染色体上に広く分布している と考えられる。また missing heritabily の項でみたよう に量的形質に関与する全ての遺伝子（あるいは連鎖す る SNP）を探すことは不可能であり、発見できない微 少な効果の遺伝子群がある限り、Hendersonの mixed model は使われ続けるのかもしれない。

一方、大量のマーカーを使う手法が新たな局面を切 り開いたことも事実である。効果的な SNPを発見した り、染色体の領域毎の働きを明らかにすることは、従 来のポリジーン効果の推定法だけでは決してできな かっただろう。またこれまでの単純なポリジーンの条 件下では（測定值のない）全きょうだいの育種価は同 じと仮定せざる終えなかった。しかしマーカー遺伝子 を用いることで全きょうだい間の差を生み出すメンデ
リアン・サンプリングを考慮した育種価推定もある程 度可能になる（長嶺 2012）。まだ克服すべき課題も 多いがいずれマーカー情報は家畜改良の現場で広く利 用されて行くと考える。比較的効果の大きい遺伝子の 探索、遺伝子の組み合わせ効果など非相加的な働きの 解明、複数の遺伝子が作り出す遺伝相関の解明など マーカーの利用によって多くのことが期待できる。た だし、現状を見る限り改良理論が根本から変わるわけ ではなく、従来の枠組みの中に新たにマーカーという 情報が加わったように思える。改良に携わる者として は過度な期待で現場が混乱しないように、将来ゲノム 情報を使って可能になることと現状で可能なことは十 分に区別して臨む必要がある。

\section{謝辞}

家畜改良センター及び家畜改良事業団より乳牛の夕 イピングデータおよび従来の育種価推定值の提供など 研究遂行のために全面的な支援と協力をいただいた。 また北海道農業研究センターの家畜育種研究者の方々 からは論文作成に当たり貴重なご助言をいただいた。 この場を借りて関係者の皆様に深謝したい。

\section{文献}

Andersson L, Haley CS, Ellegren H, Knott SA, Johansson M, Andersson K, Anderssonklund L, Edforslilja I, Fredhlm M, Hansson I, et al. 1994. Genetic-mapping of quantitative trait loci for growth and fatness in pigs. Science 263: 1771-1774.

Aulchenko YS, Ripke S, Isaacs A, Van Duijn CM. 2007. GenABEL: an R library for genorne-wide association analysis. Bioifomatics 23: 1294-1296.

Falconer DS. 1960. Introduction of quantitative genetics. 
Oliver and Boyd. Edinbugh.

Fortes MRS, Curi RA, Chardulo LAL, Silveira AC, Assumpçáo MEOD, Visintin JA, de Oliveira HN. 2009. Bovine gene polymorphisms related to fat deposition and meat tenderness. Genetics and Molecular Biology, 32: $75-82$.

Gao H, Christensen OF, Madsen P, Nielsen US, Zhang Y, Lund MS, Su G.2012.Comparison on genomic predictions using three GBLUP methods and two singlestep blending methods in the Nordic Holstein population. Genetics Selection Evolution, 44:8, http:// www.gsejournal.org/content/44/1/8

Haley SC, Visscher PM. 1998. Strategies to utilize markerquantitative trait loci associations. Journal of Dairy Science 81: 85-97.

Hayes BJ, Visscher PM, Goddard ME. 2009. Increased accuracy of artificial selection by using the realized relationship matrix. Genetics Research 91: 47-60.

Hayes BJ, Pryce J, Chamberlain AJ, Bowman PJ, Goddard ME. 2010. Genetic architecture of complex traits and accuracy of genomic prediction: coat colour, milk-fat percentage, and type in Holstein cattle as contrasting model traits. PLOS Genetics 6: e1001139.

Henderson, C.R., 1973. Sire evaluation and genetic trends. In: Proc. Anim. Breeding Genetics Symp. in Honour of J.L. Lush. Am. Soc. Anim. Sci. and Am. Dairy Sci. Assoc., Champaign, IL, pp. 10-41.

Henderson CR. 1984. Application of linear models in animal breeding. Univrsity of Guelph, Ontario.

Iwaisaki H, Arakawa A, Matsuda H. 2010. Beefing-up genomic evaluation Genomic selection: some selected topics. 家畜育種研究会報 18: 17-49.

Knott SA, Marklund L, Haley CS, Andersson K, Davies W, Ellegren H, Fredholm M, Hansson I, Hoyheim B, Lundstrom K, et al. 1998. Multiple marker mapping of quantitative trait loci in a cross between outbred wild boar and large white pigs. Genetics 149: 1069-1080.

Lettre G, Jackson AU, Gieger C, Schumacher FR, Berndt SI, Sanna S, Eyheramendy S, Voight BF, Butler JL, Guiducci C, et al. 2008. Identification of ten loci associated with height highlights new biological pathways in human growth. Nature Genetics 40: 584-591.

Maher B.2008.Personal genomes: The case of the missing heritability.Nature 456: 18-21.
Meuwissen THE, Hayes BJ, Goddard ME.2001. Prediction of total genetic value using genome-wide dense marker maps. Genetics 157: 1819-1829.

Meuwissen THE. 2007. Genomic selection: marker assisted selection on a genome wide scale. Journal of Animal Breeding and Genetics 124: 321-322.

Mrode R, Moore K, Winters M, Coffey M. 2012. Evaluating the impact of including residual plogenic effects in dairy genomic evaluations using Bayesian methods. Interbull Bulletin. 46: 109-114.

Nagamine Y, Visscher PM, Haley CS. 2004. QTL detection and allelic effects for growth and fat traits in outbred pig populations. Genetics Selection Evolution. 36: 83-96.

Nagamine Y, Pong-Wong R, Navarro P, Vitart V, Hayward C, Rudan I, Campbell H, Wilson J, Wild S, Hicks AA, et al. 2012a, Localising Loci underlying Complex Trait Variation Using Regional Genomic Relationship Mapping. PLOS ONE. 7(10): e46501.

Nagamine Y, Pong-Wong R, Navarro P, Hagiya K, Yamazaki T, Haley CS. 2012b, Localising genomic variance of production traits in dairy cattle using regional genomic relationship mapping. Proceedings International Conference of Quantitative Genetics, 17-22 June 2012, Edinburgh, UK

長嶺慶隆. 2012. SNP マーカーを用いたゲノム研究と今 後の家畜育種。日本畜産学会報.83（1）: 1-8.

Nejati-Javaremi A, Smith C, Gibson JP. 1997. Effect of total allelic relationship on accuracy of evaluation and response to selection. Journal of Animal Science. 75: 1738-1745.

Pong-Wong R, George AW, Woolliams JA, Haley CS. 2001. A simple and rapid method for calculating identity-bydescent matrices using multiple markers. Genetics Selection Evolution. 33: 453-471.

Purcell S, Neale B, Todd-Brown K, Thomas L, Ferreira MAR, Bender D, Maller J, Sklar P, de Bakker PIW, Daly MJ, Sham PC. 2007. PLINK: a tool set for wholegenome association and population-based linkage analyses. American Journal of Human Genetics. 81: 559-575.

佐分淳一. 2010. ジェノミックを利用した遺伝的能力評 価の試み。畜産技術 666: 2-5.

Schaeffer LR. 2006. Strategy for applying genome-wide selection in dairy cattle. Journal of Animal Breeding 
and Genetics. 123: 218-223.

Schnabel RD,Sonstegard TS, Taylor JF, Ashwell MS. 2005. Whole-genome scan to detect QTL for milk production, conformation, fertility and functional traits in two US Holstein families. Animal Genetics. 36: 408-416.

Spelman RJ, Ford CA, McElhinney P, Gregory GC, Snell RG. 2002. Characterization of the DGAT1 gene in the New Zealand dairy population. Journal of Dairy Science 85: 3514-3517.

Sullivan PG, Zumbach B, Durr JW, Jakobsen JH. 2011. International genomic evaluations for young bulls. In: The 2011 Interbull Meeting, 26-28 August 2011, Stavanger, Norway.

VanRaden PM. 2008. Efficient Methods to Compute Genomic Predictions. Journal of Dairy Science. 91: 4414-4423.

VanRaden PM, Van Tassell CP, Wiggans GR, Sonstegard TS, Schnabel RD, Taylor JF, Schenkel FS. 2009. Invited review: Reliability of genomic predictions for North American Holstein bulls. Journal of Dairy Science 92, 16-24.

Visscher PM, Macgregor S, Benyamin B, Zhu G, Gordon S, Medland SE, Hill WG, Hottenga JJ, Willemsen G, Boomsma DI, et al. 2007. Genome Partitioning of Genetic Variation for Height from 11,214 Sibling Pairs. American Journal of Human Genetics 81: 1104-1110.

Vitart V, Rudan I, Hayward C, Gray NK, Floyd J, Palmer CN, Knott SA, Kolcic I, Polasek O, Graessler J, et al. 2008. SLC2A9 is a newly identified urate transporter influencing serum urate concentration, urate excretion and gout. Nature Genetics 40: 437-442.

Weedon MN, Lango H, Lindgren CM, Wallace C, Evans DM, Mangino M, Freathy RM, Perry JRB, Stevens S, Hall AS, et al. 2008. Genome-wide association analysis identifies 20 loci that influence adult height. Nature Genetics 40: 575-583.

Winter A, Krämer W, Werner FA, Kollers S, Kata S, Durstewitz G, Buitkamp J, Womack JE, Thaller G, Fries R. 2002. Association of a 1ysine-232/alanine polymorphism in a bovine gene encoding acylCoA:diacylglycerol acyltransferase (DGAT1) with variation at a quantitative trait locus for milk fat content. Proc Natl Acad Sci U S A. 99(14):9300-9305.

Yang J, Benyamin B, McEvoy BP, Gordon S, Henders AK, Nyholt DR, Madden PA, Heath AC, Martin NG,
Montgomery GW, Goddard ME, Visscher PM. 2010. Common SNPs explain a large proportion of the heritability for human height. Nature Genetics 42: 565-569. 